\title{
A Different Independence Day Celebration
}

A 50 member delegate of The Bangladesh Society of Medicine (BSM) attended the WCIM 2010 held in Melbourne, Australia from $20^{\text {th }}$ to $25^{\text {th }}$ March 2010 . The team was headed by the President of the Society Prof. M.A. Jalil Chowdhury and was the second largest participant in the Congress. Two papers of Prof. Quazi Tarikul Islam was accepted by the congress committee one for oral and the other for poster presentation, both of which was highly appreciated by the international fraternity. The delegates had an extensive tour of Australia following the conference which was a breather for the other wise extremely busy physicians. The tour included the Phillips Island Penguin parade, Melbourne city tour and Great Ocean Road tour in Melbourne, Sydney city site seeing and Blue mountain tour in Sydney, A whole day visit to Canberra, Great Reef Cruises in Cairns and finally cruising through Brisbane and Gold Coast before departing for Dhaka.

Through out the period the delegates were enthusiastically greeted by expatriate doctors and they were overwhelmed to see such a massive delegation from Bangladesh attending the conference.

The most memorable event for all was the celebration of Independence Day out side the country and that to on the way from Sydney to Blue Mountains. The occasion was commemorated by a small program on the wheels conducted by Prof. Khan Abul Kalam Azad, which saw the participation of the whole contingent in a spirited and emotional manner reminding all once again the spirit of Independence and how proud all were to represent Bangladesh. The whole contingent sang the National Anthem to start with followed by narration of personal accounts and losses during the liberation from Prof. Sheikh Nesar Uddin, Prof. Quazi Tarikul Islam, Prof. HAM Nazmul Ahasan and his spouse, Prof. Jalil Chowdhury, Dr. Billal Alam, Prof. Mohammad Mohsin, Prof. Kazi Md. Jahangir, Prof. CN Sarker, lt. Col. Mamun Mustafi, Prof Kaniz Mowla, Prof. Md. Ismail Patwari along with his spouse Dr. Kamrun Nahar and Dr. Sohel. Tears trickled and sighs were heard but at the end of the program to all the only thing that mattered was the country and its courageous people had achieved what they fought for.

The journey 'Down Under' turned out to be one of the most memorable and successful venture for Bangladesh Society of Medicine. Not only has views been exchanged and knowledge expanded but also the otherwise busy physicians had a well deserved break before returning to their duties fully charged up. 